\title{
Professor George Coedès, 1866-1969: A Memoir
}

MILTON OSBORNE

The world of Southeast Asian scholarship has suffered an immeasurable loss with the death in October 1969 of Professor George Coedès, the undisputed doyen of those who have studied the early history of the region. In a lifetime of scholarly activity, beginning with the publication of his first article on the early history of Cambodia in 1904, Professor Coedès prepared a rich heritage for those who seek to understand the intricacies of the history and culture of the Indianised states of Southeast Asia.

Many of the appreciations which will be published following Professor Coedès' death will come from the pens of scholars who have worked in the same field of early Southeast Asian history. It may not be inappropriate, however, that one of the many tributes to his memory should come from a student of Southeast Asian history whose interests are directed towards more recent times; not inappropriate since all students of Southeast Asia, no matter how contemporary their preoccupations, are indebted to Professor Coedès' studies and the fundamental foundation which they provide for analysis and interpretation of developments in the area. Moreover, and to inject a personal note which can scarcely be omitted when one comes to consider the passing of a great scholar with whom one has had some personal association, this present memoir is written with the lasting memory of hours spent in Professor Coedès' Paris study listening to and benefiting from the accumulated knowledge which he had stored up over sixty years.

Professor Coedès will be best remembered by the general student of Southeast Asian history for his massive work of synthesis, Les Etats hindouisés d'Indochine et d'Indonésie; first published with a slightly different title in 1944, and then republished in 1947 and 1963, before being published for the first time under its English title, The Indianized States of Southeast Asia, in 1968.

The very worth and importance of this study stems, however, from the mass of detailed and painstaking reasearch which characterised Professor Coedès' lifelong commitment to scholarship. Where other scholars have aspired to publish a book incorporating their reaserches, Professor Coedès worked steadily on a series of papers, monographs and books, so that a bibliography of his work, which did not include writings published after 1962, extended over more than twenty pages.

It may be that Professor Coedès' most important single gift to the study of Southeast Asian history lay in his rediscovery of the early Indonesian maritime empire of Srivijaya. Yet, it is probably reasonable to suggest that his most consistent interest was in the history of Cambodia, and above all in the life of the outstanding ruler, Jayavarman VII, whose life and achievements have been revealed and assessed in so many of Professor Coedès' writings.

Following in the tradition of the great French epigraphists, Professor Coedès devoted much of his life to the collation and translation of all the extant inscriptions of the early Cambodian empires. If the rediscovery of Srivijaya may be seen as his greatest gift to original scholarship, the translations and annotations contained in the eight volumes of Les Inscriptions du Cambodge represent the most important single corpus of epigraphic research to be prepared by an individual scholar of Southeast Asia in the present century.

It would be wrong, in attempting to assess Professor Coedès' achievement, to leave the impression that his scholarship was removed from the interests of all but those who seek the most detailed introduction to events in the past. That his Les Etats hindouisés d'Indochine et d'Indonésie is of importance to the general student has already been noted. He successfully applied his vast knowledge to the preparation of two notable works of vulgarisation, Pour mieux comprendre Angkor (translated into English as Angkor an Introduction), and, Les Peuples de la péninsule indochinoise (translated into English as The Making of Southeast Asia). These books provide the reader with insights and commentary which although prepared for a non-specialist audience are informed 
by the deep scholarship of their author.

Honours and awards marked Professor Coedès' life. Having held the post of Director of the Ecole Francaise d'Extrême-Orient, he was later given the title of Honorary Director. He was a Member of the Institut de France, a tribute both to his scholarship and to his long association with the Ecole Francaise, one of the most distinguished of the French Government's institutes of research.

Each academic discipline has its share of elder scholars whose scholarship and personality have set them at the head of their profession. It would be rash to claim that those who study the history of Southeast Asia have been more fortunate than scholars in other fields in this matter. That they have been fortunate is surely beyond dispute.

I will always be grateful that my own studies should have led me to Paris, and so to the opportunity to meet and talk with Professor Coedès on several occasions. I do regard it as my singular fortune to have added this personal experience to the disciplined fascination which comes from reading and studying his writings. No teacher could have been kinder to an itinerant graduate student whose main interests were in the nineteenth century than was Professor Coedès. Only a man with a burning interest in the past could have accomplished his work. This acute interest, combined with considerable skill as a raconteur, was one of the hallmarks of his writing. 